\title{
Assessment of Mercury-Polluted Soils Adjacent to an Old Mercury-Fulminate Production Plant
}

\author{
M. Camps Arbestain, ${ }^{1,2}$ L. Rodríguez-Lado, ${ }^{1,3}$ M. Bao, ${ }^{4}$ and F. Macías ${ }^{1}$ \\ ${ }^{1}$ Departamento de Edafología y Química Agrícola, Facultad de Biología, Universidad de Santiago de Compostela, \\ 15782 Santiago de Compostela, Spain \\ ${ }^{2}$ Department of Agroecosystems and Natural Resources, NEIKER Instituto Vasco de Investigación y Desarrollo Agrario, \\ Berreaga 1, 48160 Derio (Bizkaia), Spain \\ ${ }^{3}$ European Commission, Directorate General JRC, Institute for Environment and Sustainability, \\ TP 280, Via E. Fermi 2749, 21027 Ispra (VA), Italy \\ ${ }^{4}$ Departamento de Ingeniería Química, Facultad de Química, Universidad de Santiago de Compostela, \\ 15706 Santiago de Compostela, Spain
}

Correspondence should be addressed to M. Camps Arbestain, mcamps@neiker.net

Received 12 February 2008; Accepted 28 September 2008

Recommended by Yong-Guan Zhu

Mercury contamination of soils and vegetation close to an abandoned Hg-fulminate production plant was investigated. Maximum concentrations of $\mathrm{Hg}\left(>6.5 \mathrm{~g} \mathrm{~kg}^{-1}\right.$ soil) were found in the soils located in the area where the wastewater produced during the washing procedures carried out at the production plant used to be discharged. A few meters away from the discharge area, $\mathrm{Hg}$ concentrations decreased to levels ranging between 1 and $5 \mathrm{~g} \mathrm{~kg}^{-1}$, whereas about 0.5 ha of the surrounding soil to the NE (following the dominant surface flow direction) contained between 0.1 and $1 \mathrm{~g} \mathrm{~kg}^{-1}$. Mercury contamination of soils was attributed (in addition to spills from $\mathrm{Hg}$ containers) to (i) $\mathrm{Hg}$ volatilization with subsequent condensation in cooler areas of the production plant and in the surrounding forest stands, and (ii) movement of water either by lateral subsurface flow through the contaminated soils or by heavy runoff to surface waters.

Copyright ( 2009 M. Camps Arbestain et al. This is an open access article distributed under the Creative Commons Attribution License, which permits unrestricted use, distribution, and reproduction in any medium, provided the original work is properly cited.

\section{Introduction}

Mercury is often found in soils as "hot spots" located close to industrial facilities that either use $\mathrm{Hg}$ in their fabrication processes (e.g., chlor-alkali plants) or produce $\mathrm{Hg}$ compounds (e.g., Hg-fulminate plants). The type of reactions that take place during the production process, as well as during transportation and disposal,

largely determines the chemical composition and distribution of $\mathrm{Hg}$ in the surrounding environment [1]. Mercuryfulminate $\left(\mathrm{Hg}(\mathrm{OCN})_{2}\right)$ used to be produced as a primary explosive for percussion caps and as a detonator [2]. Formation of this detonating compound involves the dissolution of $\mathrm{Hg}$ in nitric acid and the addition of ethanol. Acid vapors containing ethanol and $\mathrm{Hg}$ are generated during this process, although they were usually condensed and collected within the production facilities. Wastewaters producedeither after filtering the reacting mixtures or through washing activities - were historically disposed of in the surroundings of the production plants. This explains why the soils surrounding many of these old facilities contain high levels of $\mathrm{Hg}$ contamination.

Mercury can undergo changes in speciation that are either physicochemically or biologically induced, which results in changes in solubility, toxicity, and bioavailability [3]. Thus, the weathering of $\mathrm{Hg}$ materials disposed in soils may redistribute $\mathrm{Hg}$ in other chemical forms and facilitate its dispersal in watersheds or atmospheric emissions [4]. This further complicates the characterization of these contaminated sites, which is already complex because of the very heterogeneous distribution of this type of pollutant in the environment and within samples. Moreover, the sampling 
of soils contaminated with primary explosives, such as $\mathrm{Hg}$ fulminate, is risky because of the extreme instability of these compounds [5].

Mercury is naturally present in soils at concentrations ranging between 0.003 and $4.6 \mathrm{mg} \mathrm{kg}^{-1}$ [6] —in most cases below $0.5 \mathrm{mg} \mathrm{kg}^{-1}$ [7] — whereas in contaminated sites, concentrations of up to 11500 and $14000 \mathrm{mg} \mathrm{kg}^{-1}$ have been reported $[8,9]$. In these contaminated areas-where $\mathrm{Hg}$ entrance to the system is mainly via surface spills, wastewater discharge, and/or by condensation of atmospheric $\mathrm{Hg}$ - the element tends to accumulate in the soil surface horizons, and is mainly retained by sorption onto organic compounds and, to a lesser extent, clays $[3,10]$. Maximum sorption onto soil organic surfaces occurs in the range of $\mathrm{pH} 3$ to $5[11,12]$, whereas as $\mathrm{pH}$ increases, sorption decreases, mainly because of the increase in dissolved organic matter complexed with $\mathrm{Hg}$ [12]. Thioligands appear to be mainly responsible for $\mathrm{Hg}$ binding to organic compounds [13] and, in general, organic matter exerts a dominant influence on $\mathrm{Hg}$ binding, transformation, and transport processes [14]. Other factors affecting $\mathrm{Hg}$ retention in surface soils, in addition to organic matter, are (i) chemical properties, such as soil $\mathrm{pH}$ and redox potential, which affect $\mathrm{Hg}$ speciation and solubility [15], (ii) amount and type of mineral colloids [16], (iii) presence of $\mathrm{Cl}^{-}$ligands $[12,17]$, and (iv) soil temperature.

In the present study, $\mathrm{Hg}$ contamination of soils and vegetation in the surroundings of an abandoned $\mathrm{Hg}$ fulminate production plant was investigated. Digital maps of the distribution of $\mathrm{Hg}$ in the soils in the study area were generated for the different depths studied. Distribution of $\mathrm{Hg}$ in different particle-size fractions was also investigated. Additionally, the geochemical evolutionary trends of $\mathrm{Hg}$ in the contaminated soils were estimated from Eh and $\mathrm{pH}$ determinations.

\section{Materials and Methods}

2.1. Site History. The site under study (see Figure 1) is located $6 \mathrm{~km}$ from the city of Oviedo (Asturias, North West Spain), and has an extension of 90 ha. The mean annual temperature in the area is $12^{\circ} \mathrm{C}$, and total annual precipitation is $1100 \mathrm{~mm}$. Soils are classified as "Urbianthropic Regosols" [18]. The natural soils in nearby areas are Umbrisols developed from poorly developed metamorphic rocks. The plant began operations in 1866, although since then, the type of products manufactured has changed greatly. Since the plant became operational, a number of products have been manufactured, including sulphuric acid, nitroglycerine, nitroglycol, dynamite, dinitrotoluene, thrilite, and emulsions, $\mathrm{Ca}$ superphosphates, $\mathrm{Hg}$-fulminate, and BNT-DNT. Production at the plant ceased in 1996, and the facilities are currently used for the storage of commercial explosives produced in other plants. Within the study site, the former Hg-fulminate production plant is located on a low hill (220-240 m height) in the NE of the property; the site covers an area of 4.3 ha, which is dominated by a dense deciduous forest. The $\mathrm{Hg}$-fulminate production facilities occupy an area of $840 \mathrm{~m}^{2}$. In addition to this primary

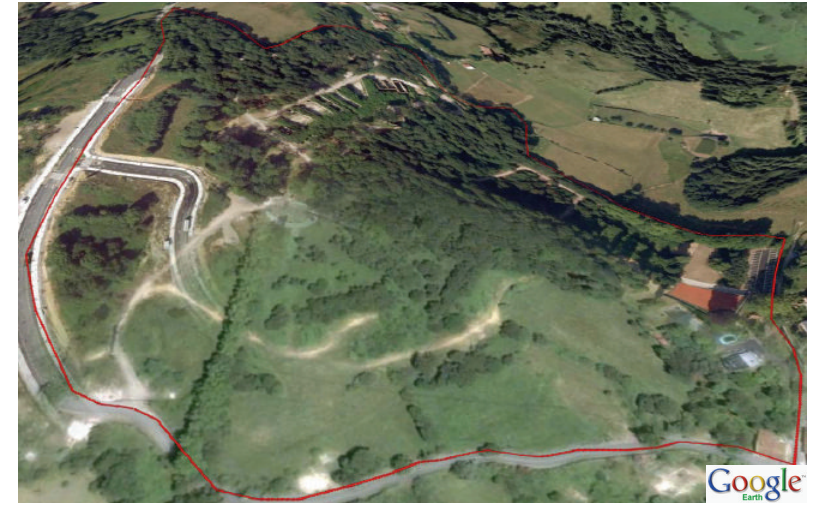

Figure 1: View of the study area (source: Google Earth).

explosive, other materials, mainly penthrite (PETN) and TNT, used to be stored in the area.

2.2. Sampling and Sample Preparation. A total of 37 sampling points (28 within the area of $\mathrm{Hg}$-fulminate production and 9 in the surrounding area) were sampled taking into account the position of possible sources of $\mathrm{Hg}$ contamination (e.g., areas of storage, production, discharge, etc.) as well as the possible sinks. Soil samples were collected from different depths, down to the presence of a compacted layer (e.g., a rock, clay sediments, or concrete), and a total of 127 soil samples were analyzed for $\mathrm{Hg}$. All soils were found to be highly disturbed by the construction of the explosive production facilities. Soils were air-dried, thoroughly mixed, and ground to pass through a $2 \mathrm{~mm}$ sieve, before use. Twenty-three of the soil samples were selected for a more detailed analysis. Of these, $\mathrm{Hg}$-contaminated samples covering the whole $\mathrm{pH}$ range of the soils from the area were chosen. Particle-size fractionation of some soil samples was carried out by sieving to separate the following fractions: coarse sand (1-2 mm), fine sand $(0.2-1 \mathrm{~mm})$, very fine sand $(0.2-0.05 \mathrm{~mm})$, silt + clay $(<0.05 \mathrm{~mm})$. Organic matter was not removed from the soil samples.

2.3. Soil Chemical Analyses. The total Hg concentration was determined in dry soil samples, with an LECO AMA-254 combustion $\mathrm{Hg}$ analyzer (LECO Corp., St. Joseph, Mich, USA). This system determines $\mathrm{Hg}$ directly by combustion, amalgamation, concentration on a gold filter, and spectrometry. Several certified NIST standards were used (e.g., 2782 industrial sludge and 1633 trace elements in coal fly ash).

Soil samples in which the concentration of $\mathrm{Hg}$ was $>10 \mathrm{mg} \mathrm{kg}^{-1}$ were diluted with commercial kaolinite. Comparison of $\mathrm{Hg}$ concentrations obtained with and without dilution with kaolinite showed a good recovery (data not shown). Soil $\mathrm{pH}$ was measured in $\mathrm{H}_{2} \mathrm{O}$ and $\mathrm{KCl}$ in a soil:solution ratio of $1: 2.5$. The $\mathrm{pH}$ of oxidation was also measured 6 hours after the addition of $100 \mathrm{~mL}$ of $\mathrm{H}_{2} \mathrm{O}_{2}$ to $5 \mathrm{~g}$ of soil [19]. Organic $\mathrm{C}$ in the selected soil samples was analyzed by combustion with an LECO carbon analyzer (model CHN-1000, LECO Corp.) (soil samples of $\mathrm{pH}>5.6$ were previously treated with concentrated 
TABLE 1: Values of $\mathrm{pH}$ in water, $\mathrm{KCl}$, and $\mathrm{H}_{2} \mathrm{O}_{2}$ ( $\mathrm{pH}$ of oxidation), Eh of selected soil samples, organic $\mathrm{C}$ content, and $\mathrm{Hg}$ concentration of selected soil samples. Standard errors of $\mathrm{Hg}$ concentrations are indicated in parentheses $(n=4)$.

\begin{tabular}{|c|c|c|c|c|c|c|c|c|}
\hline Site & Horizon & $\begin{array}{c}\text { Depth } \\
(\mathrm{cm})\end{array}$ & $\mathrm{pH}-\mathrm{H}_{2} \mathrm{O}$ & $\mathrm{pH}-\mathrm{KCl}$ & pH-oxidation & $\begin{array}{c}\text { Eh } \\
(\mathrm{mV})\end{array}$ & $\begin{array}{c}\text { Organic C } \\
\left(\mathrm{g} \mathrm{Kg}^{-1}\right)\end{array}$ & $\begin{array}{l}\text { Hg conc. } \\
\left(\mathrm{mg} \mathrm{kg}^{-1}\right)\end{array}$ \\
\hline $\mathrm{I}-8$ & $\mathrm{O}$ & & 5.90 & 6.21 & 4.09 & 468 & 182.0 & $838(22)$ \\
\hline $\mathrm{I}-8$ & Ah1 & $0-10$ & 6.73 & 6.63 & 4.99 & 503 & 18.2 & $234(6)$ \\
\hline P-6 & Ah1 & $0-10$ & 6.52 & 6.40 & 6.42 & 484 & 57.0 & $6.96(0.12)$ \\
\hline A-2 & Ah1 & $0-15$ & 6.20 & 5.75 & 5.34 & 278 & 19.0 & $33.6(1.2)$ \\
\hline M-2 & Ah1 & $0-10$ & 7.10 & 7.58 & 6.44 & 268 & 75.0 & 3377 (39) \\
\hline M-3 & Ah1 & $0-10$ & 7.59 & 7.46 & 5.96 & 288 & 78.0 & $5883(252)$ \\
\hline M-4 & Ah1 & $0-5$ & 7.58 & 7.27 & 5.93 & 284 & 104.0 & $6350(135)$ \\
\hline M-5 & Ah1 & $0-5$ & 7.68 & 7.67 & 6.44 & 396 & 15.0 & $1546(81)$ \\
\hline M-6 & Ah1 & $0-20$ & 7.07 & 6.83 & 5.86 & 200 & 56.0 & $1687(222)$ \\
\hline M-9 & Ah1 & $0-30$ & 5.95 & 4.94 & 5.36 & 281 & 12.0 & $26.4(0.2)$ \\
\hline M-10 & Ah1 & $0-5$ & 6.93 & 6.52 & 4.83 & 275 & 89.0 & 9043 (779) \\
\hline M-11 & Ah1 & $0-20$ & 5.36 & 4.81 & 4.05 & 533 & 64.9 & $392(5)$ \\
\hline M-12 & Ah1 & $0-20$ & 4.76 & 4.51 & 3.20 & 485 & 120.0 & $280(6)$ \\
\hline P-11 & Ah2 & $10-20$ & 7.45 & 7.12 & 6.27 & 426 & 34.8 & $43.7(1.1)$ \\
\hline L-4 & Ah2 & $10-20$ & 4.24 & 3.93 & 3.78 & 620 & 30.2 & $50.7(3.0)$ \\
\hline $\mathrm{L}-4$ & CA & $70-80$ & 7.79 & 7.44 & 6.50 & 454 & 15.8 & $421(15)$ \\
\hline P-13 & $\mathrm{C}$ & $10-20$ & 4.22 & 4.16 & 4.20 & 551 & 4.2 & $109(2)$ \\
\hline P-14 & $\mathrm{C}$ & $8-15$ & 4.08 & 4.27 & 4.45 & 543 & 7.4 & $132(2)$ \\
\hline P-15 & $\mathrm{C}$ & $10-18$ & 5.64 & 5.86 & 6.13 & 502 & 7.2 & $150(11)$ \\
\hline P-15 & $\mathrm{C}$ & $18-43$ & 4.23 & 3.78 & 4.15 & 549 & 3.9 & $212(9)$ \\
\hline P-15 & $\mathrm{C}$ & $43-93$ & 3.88 & 4.71 & 3.93 & 543 & 8.0 & $35.3(1.6)$ \\
\hline P-16 & $\mathrm{C}$ & $10-30$ & 3.87 & 3.61 & 3.32 & 639 & 6.1 & $27.1(1.9)$ \\
\hline P-8 & $\mathrm{C}$ & $78-210$ & 7.38 & 8.04 & 7.28 & 423 & 5.0 & $2.46(0.06)$ \\
\hline
\end{tabular}

$\mathrm{HCl}$ to eliminate carbonates for organic $\mathrm{C}$ determination). The redox potential (Eh) of the selected soil samples was measured in the laboratory as follows. Distilled water was added to the dried and sieved soil until a saturated paste was achieved; the mixture was then allowed to dry with the Eh electrode immersed in it. The Eh potential was read once the soil reached field capacity (24-36 hours later), when changes in Eh were $\leq 2 \mathrm{mV} \mathrm{min}^{-1}$. The Eh values obtained are approximations, as because with this methodology the effects of soil structure and of many biotic processes on redox potential are overlooked. However, experiments carried out with A horizons of forest soils from NW Spain showed differences between field Eh measurements (at field capacity) and laboratory Eh measurements (following the above described methodology) $\leq 50 \mathrm{mV}$ (Macías, unpublished data).

2.4. Plant Analyses. Foliar samples of Rubus fruticosus L., Osmunda cinnamomea (fern), and Acer sp. were collected at different sites around the former production plant, which differed in terms of the $\mathrm{Hg}$ concentrations in the soil. Foliar samples of the three species were also taken from a noncontaminated site in Galicia, under similar climatic conditions, but located some $300 \mathrm{~km}$ away from the study area. Foliar samples were washed successively with distilled water, air-dried, and ground before analyses. The total concentration of $\mathrm{Hg}$ was determined in dry foliar samples with the same LECO AMA-254 combustion Hg analyzer.

2.5. Mapping/Kriging. A georeferenced soil database was constructed using soil sample position and $\mathrm{Hg}$ concentration for each soil layer. The distribution of the maximum $\mathrm{Hg}$ concentration in the area was firstly calculated using ordinary kriging as the spatial interpolator. There was a single spot with an extremely high $\mathrm{Hg}$ concentration $\left(30 \mathrm{~g} \mathrm{~kg}^{-1}\right.$ soil), which was not included in this process as the contamination was very local, and this would have distorted the interpolation. Secondly, three levels of risk for soil $\mathrm{Hg}$ concentrations (40, 100, and $1000 \mathrm{mg} \mathrm{kg}^{-1}$ ) were established and, for each soil profile, the soil depth at which such values were reached was determined, and the corresponding maps generated. The maps were overlain on a digital elevation model so that the influence of topography on the distribution of $\mathrm{Hg}$ in the study area could be inferred. Total concentration of $\mathrm{Hg}$ of $40 \mathrm{mg} \mathrm{kg}^{-1}$ corresponds to the threshold value for industrial areas in several autonomous regions within Spain (e.g., the Basque Country).

\section{Results and Discussion}

3.1. General Soil Properties in the Study Area. The $\mathrm{pH}$ of the soils in the surroundings of the $\mathrm{Hg}$-fulminate facilities varied 


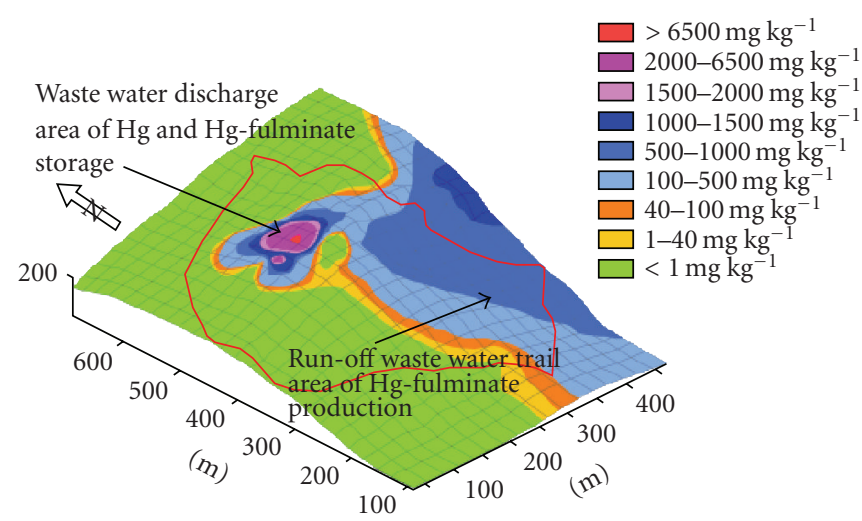

(a)

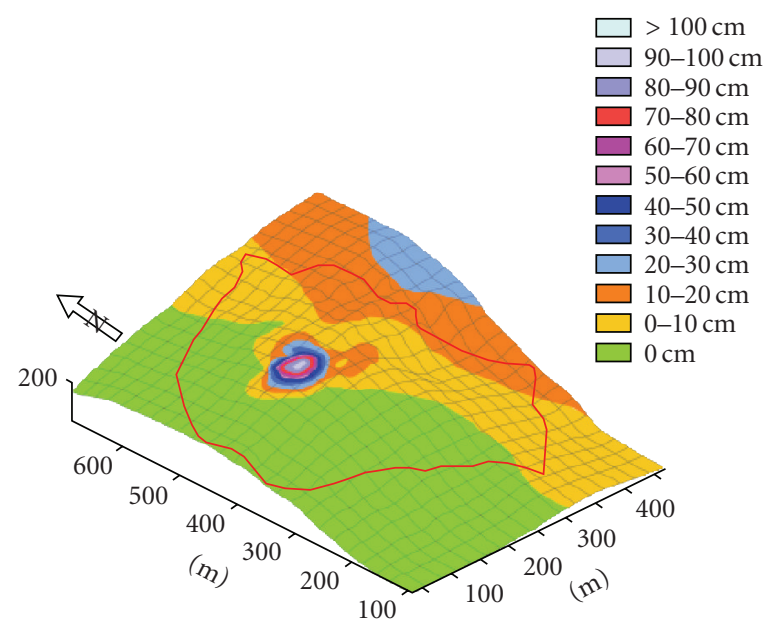

(c)

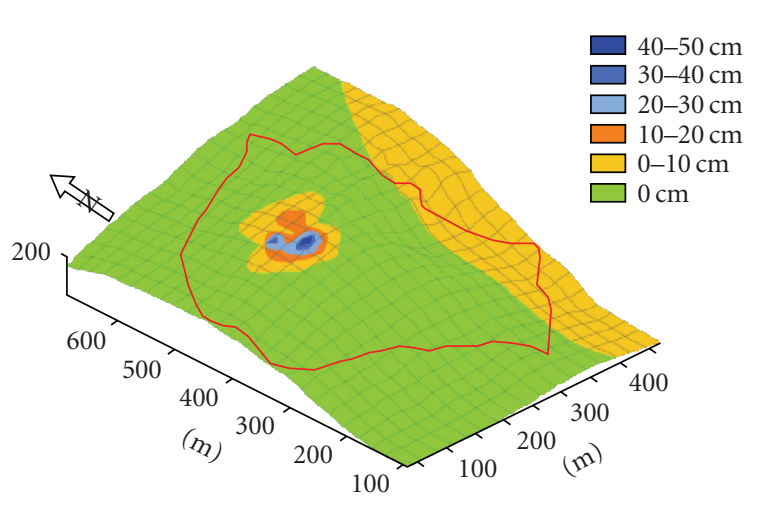

(b)

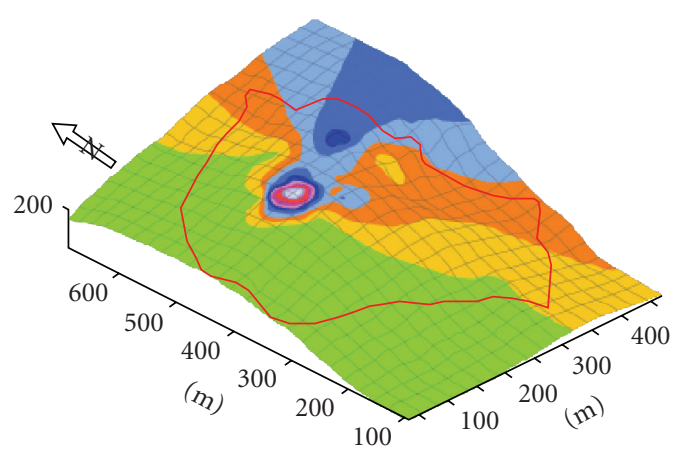

(d)

FIGURE 2: Digital maps of $\mathrm{Hg}$ distribution in the soils of the area around the Hg-fulminate facilities. (a) Surface Hg concentrations, (b), (c), and (d) depths to which $\mathrm{Hg}$ concentrations reached values above $1,0.1$, and $0.04 \mathrm{~g} \mathrm{~kg}^{-1}$, respectively.

widely (see Table 1 ). Soil $\mathrm{pH}-\mathrm{H}_{2} \mathrm{O}$ values of these samples ranged from 3.9 to 7.8 , and those of $\mathrm{pH}-\mathrm{KCl}$ from 3.6 to 8.0, whereas natural soils in the area are moderately acidic (with surface horizons of $\mathrm{pH} 4-5$ and subsurface horizons of $\mathrm{pH} 5$ 6) [20]. The diverse activities carried out in the production plant have caused changes in the acid-base conditions of the soils. In areas close to where lime or concrete were applied, $\mathrm{pH}-\mathrm{H}_{2} \mathrm{O}$ values are above 6 , whereas in areas with presence of untreated green pyrite and pyrite cinder wastesboth of which are wastes from the production of sulphuric acid- $\mathrm{pH}-\mathrm{H}_{2} \mathrm{O}$ values are below 4 . Organic $\mathrm{C}$ contents of mineral surface horizons of the selected soils ranged from 12 to $120 \mathrm{~g} \mathrm{~kg}^{-1}$, whereas those of subsurface horizons ranged from 4 to $16 \mathrm{mg} \mathrm{kg}^{-1}$ (see Table 1). Soils in the surroundings of the production plant were also found to be contaminated with other heavy metals in addition to $\mathrm{Hg}$, such as $\mathrm{Zn}$, $\mathrm{Cu}, \mathrm{Pb}, \mathrm{Cd}$, and $\mathrm{As}$ (data not shown), which are associated with the presence of pyrite cinder wastes, although the contaminated areas did not always coincide. The present study focuses on the area within the production plant that is contaminated with $\mathrm{Hg}$.
3.2. Mercury Distribution in the Soils of the Study Area. Digital maps of $\mathrm{Hg}$ distribution in the surface horizons of soils in the area around the Hg-fulminate facilities were generated (see Figure 2). Extremely high levels of $\mathrm{Hg}$ were detected in the discharge area for the wastewater produced during the washing procedures in the production plant (see Figure 2(a)), with concentrations higher than $6.5 \mathrm{~g} \mathrm{~kg}^{-1}$ (with a very highly contaminated spot in which $\mathrm{Hg}$ concentration in the first $5 \mathrm{~cm}$ depth was $30 \mathrm{~g} \mathrm{~kg}^{-1}$, although this was not included in the interpolation to avoid distortion of the $\mathrm{Hg}$ concentration gradients). In this highly contaminated spot, elemental $\mathrm{Hg}$ was visually identified as droplets. Some distance away from the trail of runoff wastewater, $\mathrm{Hg}$ concentrations decreased to levels ranging between 1 and $5 \mathrm{~g} \mathrm{~kg}^{-1}$. Mercury concentrations were also high in the NE vicinity of the production plant, with values above $0.1 \mathrm{~g} \mathrm{~kg}^{-1}$, covering an extension of $\sim 0.5 \mathrm{ha}$, in contrast with the concentration of $0.003 \mathrm{mg} \mathrm{kg}^{-1} \mathrm{Hg}$ detected in a noncontaminated parent material in the soils close to the study area. The results thus show a typical point source distribution pattern, with $\mathrm{Hg}$ levels decreasing with distance from the production plant. 


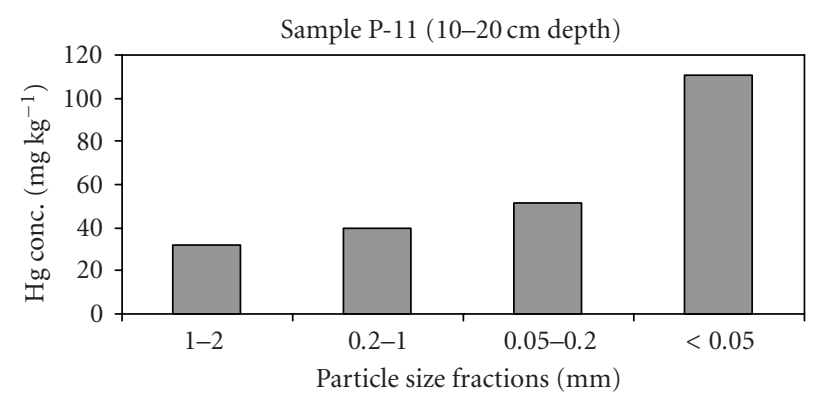

(a)

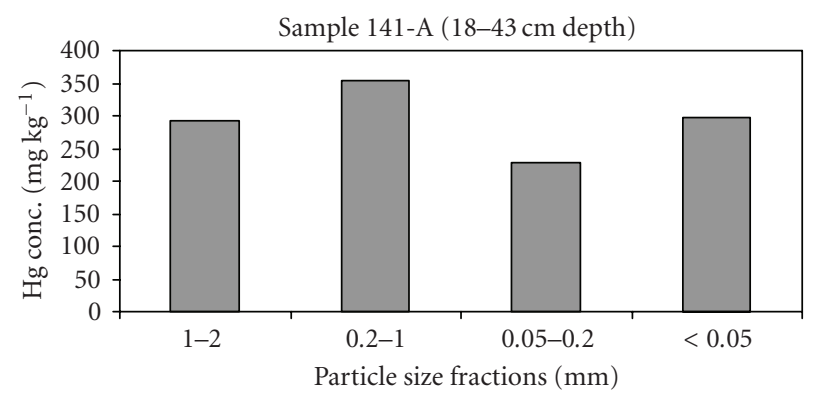

(c)

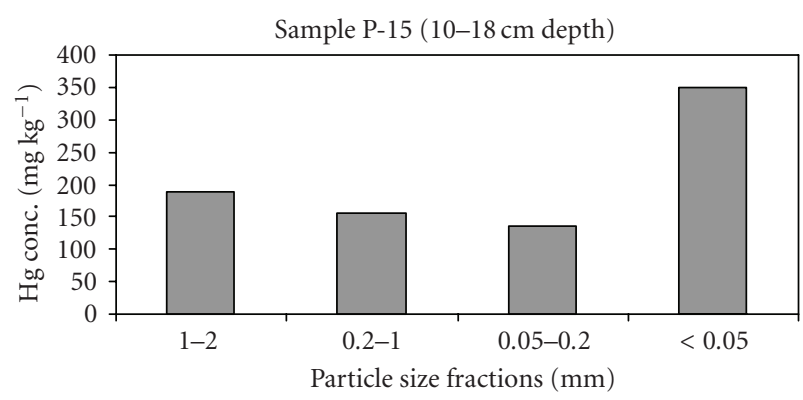

(b)

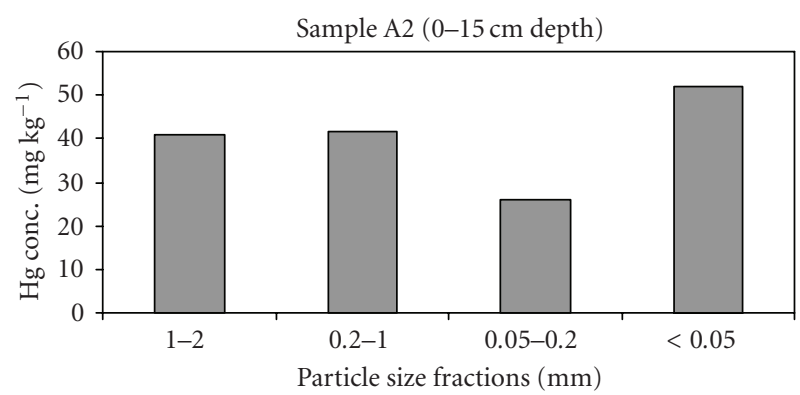

(d)

FIgURE 3: Concentration of $\mathrm{Hg}$ within the different particle-size subsamples of selected soil samples.

Mercury is generally of low mobility because of its high density, which explains the high concentrations in the vicinity of the disposal site, at the wastewater discharge area, and some meters downstream. In addition to wastewater discharge and spills from containers, $\mathrm{Hg}$ contamination of soils away from this point may be attributed to $\mathrm{Hg}$ volatilisationeither through the exothermic reactions of the Hg-fulminate production process or physicochemical/microbial-induced reactions occurring in contaminated soils - with subsequent condensation in cooler areas of the production plant and in the surrounding forest stands (see Section 3.5). The subsurface lateral movement of water contaminated with $\mathrm{Hg}$ mineral and organic particles in suspension over the soils, as well as heavy runoff to surface water, may also be important sources of the metal downstream (NE direction).

The furthest depths, at which the concentration of $\mathrm{Hg}$ reached values above $1,0.1$, and $0.04 \mathrm{~g} \mathrm{~kg}^{-1}$, are indicated in Figures 2(b), 2(c), and 2(d), respectively. In two contiguous sampling points close to the production plant, $\mathrm{Hg}$ concentrations above $1 \mathrm{~g} \mathrm{~kg}^{-1}$ were observed down to a depth of $40 \mathrm{~cm}$ (see Figure 2(b)). In this highly contaminated spot, concentrations above $0.1 \mathrm{~g} \mathrm{~kg}^{-1}$ were observed even at $1 \mathrm{~m}$ depth (see Figure 2(c)). Moreover, concentrations above $0.04 \mathrm{~g} \mathrm{~kg}^{-1}$ were also observed between 10 and $40 \mathrm{~cm}$ depth in the $\mathrm{N}$ and NE directions (see Figure 2(d)). The results obtained thus indicate high accumulation of $\mathrm{Hg}$ in surface horizons, mainly attributed to the repeated entry of the contaminant to the surface-through spills, waterflow, or condensation of volatile $\mathrm{Hg}$ - and which was probably retained in the soil by organic matter and to a lesser extent by clay particles. The presence of $\mathrm{Hg}$ in deeper horizons in the sites indicated above may be related to the downward movement of $\mathrm{Hg}$ associated with soluble organic matter, as previously reported in $[12,17]$, although more research is needed to confirm this.

3.3. Total $\mathrm{Hg}$ in the Particle-Size Subsamples. Comparison was made of the concentrations of $\mathrm{Hg}$ within the different particle size subsamples of

selected soil samples (see Figure 3). In general, the results show that $\mathrm{Hg}$ was distributed within all the particle sizes studied, and followed a relatively homogenous pattern, with a tendency for concentration to increase as the particle size decreased in the P-11 and P-15 soil samples. FernándezMartínez et al. [21] observed a generally higher Hg concentration in the finest particle-size subsamples, which was attributed to the higher $\mathrm{Hg}$ sorption capacity of clay minerals, $\mathrm{Fe}$ and $\mathrm{Al}$ oxy-hydroxides, and humus surfaces, all of which tended to concentrate in the finest grain sizes. Studies carried out to date indicate that in acid soils $(\mathrm{pH}$ $<4.5-5.5)$ the organic material is the only effective sorbent for inorganic $\mathrm{Hg}$, whereas in nearly neutral soils ( $\mathrm{pH}>5.5-$ 6 ), iron oxides and clay minerals may become more effective $[7,11,12]$. In this case, the four samples studied differed greatly in soil $\mathrm{pH}$, organic matter content, as well as in $\mathrm{Hg}$ content (see Table 1), and no relationship was found between the $\mathrm{Hg}$ distribution in these particle sizes fractions and these soil properties.

Both elemental $\mathrm{Hg}$ and $\mathrm{Hg}^{2+}$ tend to be strongly sorbed to the humic fraction of soils [7], although the former has less affinity for organic matter than $\mathrm{Hg}^{2+}$ species $[22,23]$. 
Moreover, elemental $\mathrm{Hg}$ readily vaporizes and can thus be reemitted into the atmosphere, especially during periods of high temperature [10]. Under acidic conditions, $\mathrm{Hg}^{0}$ may be oxidized into $\mathrm{Hg}(\mathrm{I})$ and $\mathrm{Hg}(\mathrm{II})$ [24], although $\mathrm{Hg}(\mathrm{I})$ does not seem to occur as a stable species in soils [7]. On the other hand, because of the strong affinity of $\mathrm{Hg}^{2+}$ for humic substances $[12,14,25]$ only trace contents of $\mathrm{Hg}^{2+}$ are generally found in soil solution [26], either as free Hg ions or as soluble $\mathrm{Hg}$ complexes, which are bioavailable. Neither speciation nor sorption processes were investigated in the present study, although the geochemical evolutionary trends of $\mathrm{Hg}$ in the contaminated soils were inferred from $\mathrm{pH}-\mathrm{Eh}$ diagrams (see Section 3.4).

3.4. Geochemical Evolutionary Trends of $\mathrm{Hg}$ in the Contaminated Soils. One of the techniques that can be used to establish the geochemical evolutionary trends of $\mathrm{Hg}$ in the contaminated soils is the consideration of $\mathrm{pH}$ and Eh values of the soil samples, and the identification of thermodynamically stable $\mathrm{Hg}$ species by means of Eh-pH diagrams, although it must be taken into consideration that these diagrams are simplified models of very complex systems. The Eh-pH diagram for an $\mathrm{Hg}-\mathrm{O}-\mathrm{H}-\mathrm{S}-\mathrm{Cl}$ system is shown in Figure 4 [27], and the Eh and $\mathrm{pH}$ values of selected soil samples from the study area are represented. The results obtained (see Figure 4) show that the group of soil samples with Eh values below $400 \mathrm{mV}$ includes all the soil samples with $\mathrm{Hg}$ concentrations above $1 \mathrm{~g} \mathrm{~kg}^{-1}$, and all correspond to surface horizons (see Table 1). According to the Eh-pH diagram, $\mathrm{Hg}^{0}$ is the most thermodynamically stable species in the first group of soils, which is consistent with the fact that these soils were sampled close to the discharge exit of wastewaters rich in $\mathrm{Hg}^{0}$.

On the other hand, the concentrations of $\mathrm{Hg}$ in all soil samples with Eh values $>400 \mathrm{mV}$ were below $1 \mathrm{~g} \mathrm{~kg}^{-1}$ (see Figure 4), and according to the Eh-pH diagram, $\mathrm{Hg}_{2} \mathrm{Cl}_{2}$, $\mathrm{Hg}_{2}{ }^{2+}$, and $\mathrm{Hg}^{0}$ were the most thermodynamically stable species under the conditions used. However, it is known that $\mathrm{Hg}(\mathrm{I})$ has the ability to disproportionate and equilibrate according to the equation $\mathrm{Hg}(\mathrm{I})=\mathrm{Hg}(0)+\mathrm{Hg}(\mathrm{II})$, with the disproportionation reaction for soils shifted to the extreme right side, because the high retention of $\mathrm{Hg}^{2+}$ [7]. Thus, $\mathrm{Hg}(\mathrm{I})$ does not appear to occur as a stable species in soil [7]. Finally, within the latter group of soil samples, the $\mathrm{pH}$ of those with Eh values above $550 \mathrm{mV}$ was below 4.3 (see Figure 4), which reveals the concurrence of very oxidant, or even hyperoxidant conditions at high acidity. This is probably related to pyrite oxidation processes, which give rise to the release of $\mathrm{H}^{+}$and $\mathrm{SO}_{4}{ }^{2-}$ into the environment.

In order to assess the potential of these soils to become further acidified by the oxidation of residual green pyrite and pyrite cinder wastes, and thus, to estimate how this would affect the future evolution of $\mathrm{Hg}$ species, the $\mathrm{pH}$ of oxidation was determined. The $\mathrm{pH}$ of oxidation establishes the minimum $\mathrm{pH}$ value that could be produced if all reduced substances were abruptly oxidized [19]. Values of $\mathrm{pH}$ in $\mathrm{H}_{2} \mathrm{O}$, $\mathrm{KCl}$, and $\mathrm{H}_{2} \mathrm{O}_{2}$ (pH of oxidation) of the selected soil samples

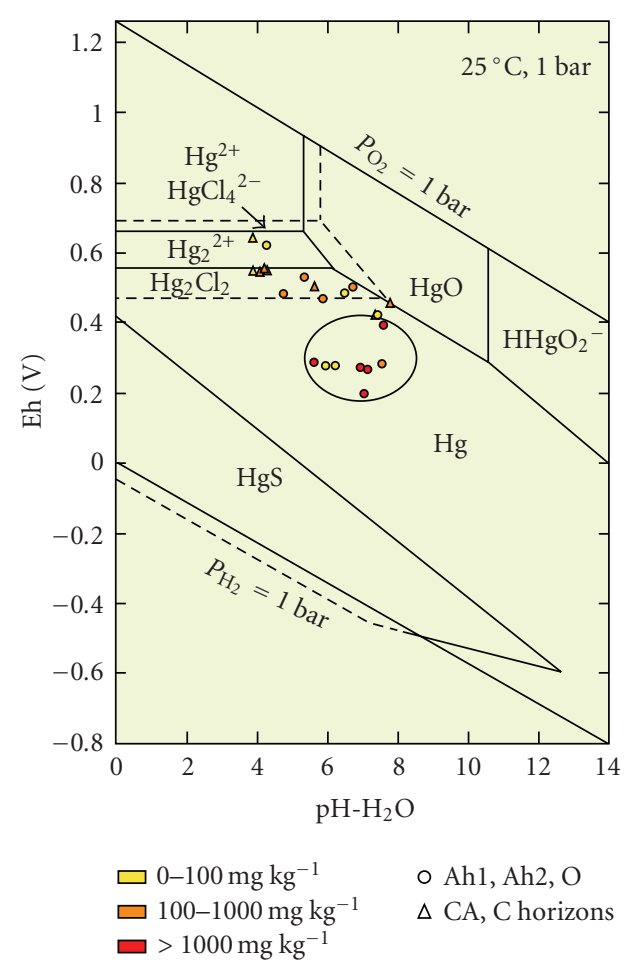

FIgure 4: Mercury Eh-pH diagram for an Hg-O-H-S-Cl system. Values of Eh and $\mathrm{pH}$ of selected soil samples are displayed. The assumed activities for dissolved species are $\mathrm{Hg}: 10^{-8} \mathrm{M}, \mathrm{Cl}: 10^{-3.5} \mathrm{M}$, and S: $10^{-3} \mathrm{M}$.

are shown in Table 1 . Comparison between values of $\mathrm{pH}$ $\mathrm{H}_{2} \mathrm{O}$ and values of $\mathrm{pH}$ of oxidation revealed a decrease in $\mathrm{pH}$ of more than 1 unit, after oxidation with $\mathrm{H}_{2} \mathrm{O}_{2}$, in eight out of the 23 selected soil samples, although $\mathrm{pH}$ values below 5 were reached in only four of the soils. The results thus indicate a low-to-moderate potential of these soils for further acidification processes.

Finally, it should be noted that several $\mathrm{Hg}$ species, such as elemental $\mathrm{Hg}$ and neutral organic $\mathrm{Hg}$ (e.g., dimethyl-Hg), have a high vapor pressure and can be a significant source of atmospheric $\mathrm{Hg}$ [28]. Over $90 \%$ of the mercury found in the atmosphere is gaseous $\mathrm{Hg}^{0}$, whereas only a small amount occurs as methylated forms, although the latter are of greater concern because of their high toxicity and bioavailability in the environment [7]. Volatile forms of $\mathrm{Hg}$ may become redistributed and deposited in nearby soils and plants as a result of condensation under higher air humidity and cooler conditions [29]. Measurements of $\mathrm{Hg}$ concentration over background vegetation tissue may thus indicate the extent of these processes, as discussed in Section 3.5

3.5. Mercury Accumulation in Plants. Foliar concentrations of $\mathrm{Hg}$ in the plants under study (Rubus fruticosus L., Osmunda cinnamomea, and Acer sp.) in the surroundings of the $\mathrm{Hg}$-fulminate production plant ranged between 0.3 to $12.7 \mathrm{mg} \mathrm{kg}^{-1}$ (see Table 2), whereas foliar Hg concentrations in the same species located in an uncontaminated site ranged between 0.03 to $0.08 \mathrm{mg} \mathrm{kg}^{-1}$ (see Table 2). Thus, the foliar 
TABLE 2: Mercury concentration of surface horizons and of leaf tissues of three different species taken at different sites in the contaminated area, except site 1 , which is a noncontaminated site located $300 \mathrm{~km}$ away from the study area but under similar climatic conditions.

\begin{tabular}{lcccccccc}
\hline & Site 1 & Site 2 & $\begin{array}{c}\text { Site 3 } \\
\mathrm{mg} \mathrm{kg}^{-1}\end{array}$ & $\begin{array}{c}\text { Site } \\
\text { Site 5 }\end{array}$ & Site 6 & Site 7 & Site 8 \\
\hline Soil & 0.03 & 14.78 & 28.2 & 37.6 & 115 & 181 & 607 & 14465 \\
fern & 0.71 & n.a. $^{(\text {a) }}$ & 3.14 & 3.36 & 4.76 & 12.37 & 12.67 & 12.26 \\
Rubus sp. & 0.33 & 0.33 & 0.45 & 0.57 & 0.99 & 2.75 & n.a. & 2.34 \\
Acer sp. & 0.75 & n.a. & 0.37 & 0.39 & n.a. & 1.89 & 0.73 & 2.43 \\
\hline
\end{tabular}

(a) n.a. Not available.

$\mathrm{Hg}$ concentrations in vegetation at the contaminated site were up to 3 times more (for Acer sp.), 8 times more (for Rubus sp.), and 17 time more (for fern) than those in plants at the uncontaminated site. On the other hand, the data obtained also indicated that the $\mathrm{Hg}$ concentration in leaves of Rubus sp. and fern increased linearly as the soil $\mathrm{Hg}$ concentration increased up to $600 \mathrm{mg} \mathrm{kg}^{-1}\left(r^{2}=\right.$ 0.66 , and 0.88 , resp.), whereas no clear relationship was found between soil and foliar $\mathrm{Hg}$ concentrations for Acer sp. Moreover, in each contaminated site, $\mathrm{Hg}$ concentrations in fern leaves were consistently higher than those in the other plants studied, suggesting a higher capacity of the former species to accumulate $\mathrm{Hg}$.

Unlike the majority of heavy metals, most $\mathrm{Hg}$ present in above-ground biomass is taken up through leaves, either as volatile $\mathrm{Hg}^{0}$ [30] or to a lesser extent, as divalent gaseous $\mathrm{Hg}$ and particulate $\mathrm{Hg}$ [31]. Uptake of $\mathrm{Hg}$ from the soil solution, through the roots, as ionic $\mathrm{Hg}$ has also been reported, but translocation to aboveground biomass is limited [32]. Thus, the high foliar $\mathrm{Hg}$ concentrations in forest stands close to the $\mathrm{Hg}$-fulminate production plant may be mainly attributed to deposition of atmospheric $\mathrm{Hg}$, as already indicated by other researchers [33]. Mercury-contaminated plants, on the other hand, can also act as a source of $\mathrm{Hg}$ to (i) the atmosphere, under low ambient air $\mathrm{Hg}$ concentrations [34], and (ii) soils and waters through litterfall [7]. In the latter case, $\mathrm{Hg}$ tends to accumulate more in forest soils than in open areas, because of the huge amount of litter produced by forest species, giving rise to a large amount of immobilized $\mathrm{Hg}$ on the forest floor. Temperature and temperature fluctuations as well as air currents are lower under the forest canopy than in open areas, whereas air humidity is higher, thus limiting $\mathrm{Hg}$ vaporization. Moreover, the larger surface area of leaves in forest vegetation exposed to $\mathrm{Hg}$ air deposition, as compared with nonforest ecosystems, may act as a large sink for atmospheric $\mathrm{Hg}$ from other sources, whereas it may impede the loss of $\mathrm{Hg}$ reemitted from the system by condensation of $\mathrm{Hg}$ as it reaches the leaves. This may explain the accumulation of $\mathrm{Hg}$ observed in soils under the dense deciduous forest vegetation of the study area located at a certain distance from the $\mathrm{Hg}$ source.

3.6. Remediation Strategy. After the characterization study, a plan for thorough cleaning up of the $\mathrm{Hg}$ contamination at the study site was established. Cleanup has entailed the excavation and removal of all contaminated material containing more than $1000 \mathrm{mg} \mathrm{kg}^{-1} \mathrm{Hg}$, from the site and its transportation to a secure dump site. No other remediation techniques such as treatment with $\mathrm{Na}$ sulphide or thermic treatments with vapor recovery for in situ remediation were implemented because of the proximity of the contaminated site to a city and the urgent need to remove the dangerous material.

\section{Conclusions}

The present study has shown the extent of contamination of soils and vegetation close to an abandoned $\mathrm{Hg}$-fulminate production plant. A highly contaminated area was identified close to the former discharge zone for the wastewater produced during the washing procedures at the plant, where the concentrations of $\mathrm{Hg}$ in the surface horizons were higher than $1 \mathrm{~g} \mathrm{~kg}^{-1}$. Analysis of the $\mathrm{Hg}$ Eh-pH diagram revealed that $\mathrm{Hg}^{0}$ is the most thermodynamically stable species in the highly contaminated surface horizons in this area, which is consistent with the visual identification of $\mathrm{Hg}$ droplets in the soil samples. On the other hand, about 0.5 ha of the surrounding soil in the NE direction (following the dominant surface flow direction) contained between 0.1 and $1 \mathrm{~g} \mathrm{~kg}^{-1} \mathrm{Hg}$. In the latter area, the oxidized $\mathrm{Hg}$ species are more thermodynamically stable than elemental $\mathrm{Hg}$, as revealed by the $\mathrm{Hg}$ Eh-pH diagram. It is possible that $\mathrm{Hg}(0)$ initially deposited in the soils was re-emitted with subsequent condensation and oxidization in cooler areas of the production plant and in the surrounding forest stands. Movement of $\mathrm{Hg}$ with water either by lateral subsurface flow through the contaminated soils or by heavy runoff to surface waters cannot be discounted. However, a more detailed investigation of $\mathrm{Hg}$ speciation in the contaminated soils is required. In any case, it should be considered that changes in atmospheric, soil climatic, physical, biological, and chemical properties may lead to short- and long-term variability in the speciation and total $\mathrm{Hg}$ concentrations in the soils in the study area.

\section{Acknowledgments}

The authors thank Carmen Pérez Llaguno, Francisco Javier Camino, and Carmen Bayón for laboratory assistance.

\section{References}

[1] R. Kucharski, U. Zielonka, A. Sas-Nowosielska, J. M. Kuperberg, A. Worsztynowicz, and J. Szdzuj, "A method of mercury removal from topsoil using low-thermal application," Environmental Monitoring and Assessment, vol. 104, no. 1-3, pp. 341351, 2005.

[2] H. Stucki, "Toxicity and degradation of explosives," CHIMIA International Journal for Chemistry, vol. 58, no. 6, pp. 409-413, 2004. 
[3] H. Biester, G. Müller, and H. F. Schöler, "Binding and mobility of mercury in soils contaminated by emissions from chloralkali plants," Science of the Total Environment, vol. 284, no. 1-3, pp. 191-203, 2002.

[4] G. E. Brown, M. S. Gustin, C. S. Kim, G. V. Lowry, and J. J. Rytuba, "Processes controlling the chemical/isotopic speciation and distribution of mercury from contaminated mine sites," National Center for Environmental, EPA grant no. R827634, 1999.

[5] A. D. Hewitt, "Detecting metallic primary explosives with a portable X-ray fluorescence spectrometer," Special Report 97-8, Cold Regions Research and Engineering Laboratory, Hanover, NH, USA, April 1997.

[6] E. Steinnes, "Mercury," in Heavy Metals in Soils, B. J. Alloway, Ed., pp. 245-259, Blackie Academics and Professional Press, London, UK, 2nd edition, 1997.

[7] K. Schlüter, "The fate of mercury in soil. A review of current knowledge. Soil and Groundwater Research Report IV," Tech. Rep. EUR 14666 EN, Commission of the European Communities, Luxembourg, UK, 1993.

[8] J. E. Gray, J. G. Crock, and B. K. Lasorsa, "Mercury methylation at mercury mines in the Humboldt River Basin, Nevada, USA," Geochemistry: Exploration, Environment, Analysis, vol. 2, no. 2, pp. 143-149, 2002.

[9] C.-M. Neculita, G. J. Zagury, and L. Deschênes, "Mercury speciation in highly contaminated soils from chlor-alkali plants using chemical extractions," Journal of Environmental Quality, vol. 34, no. 1, pp. 255-262, 2005.

[10] J. H. Rule and M. S. Iwashchenko, "Mercury concentrations in soils adjacent to a former chlor-alkali plant," Journal of Environmental Quality, vol. 27, no. 1, pp. 31-37, 1998.

[11] A. W. Andersson, "Mercury in soil," in The Biogeochemistry of Mercury in the Environment, J. O. Nriagu, Ed., pp. 79-112, Elsevier, North-Holland Biomedical Press, Amsterdam, The Netherlands, 1979.

[12] Y. Yin, H. E. Allen, Y. Li, C. P. Huang, and P. F. Sanders, "Adsorption of mercury(II) by soil: effects of $\mathrm{pH}$, chloride, and organic matter," Journal of Environmental Quality, vol. 25, no. 4, pp. 837-844, 1996.

[13] D. Wallschläger, M. V. M. Desai, M. Spengler, C. C. Windmöller, and R.-D. Wilken, "The role of humic substances in the aqueous mobilization of mercury from contaminated floodplain soils," Water, Air, \& Soil Pollution, vol. 90, no. 3-4, pp. 507-520, 1996.

[14] D. Wallschläger, M. V. M. Desai, M. Spengler, C. C. Windmöller, and R.-D. Wilken, "How humic substances dominate mercury geochemistry in contaminated floodplain soils and sediments," Journal of Environmental Quality, vol. 27, no. 5, pp. 1044-1054, 1998.

[15] T. J. Hogg, J. W. B. Stewart, and J. R. Bettany, "Influence of the chemical form of mercury on its adsorption and ability to leach through soils," Journal of Environmental Quality, vol. 7, no. 3, pp. 440-445, 1978.

[16] M. Cruz-Guzmána, R. Celis, M. C. Hermosína, P. Leone, M. Nègre, and J. Cornejo, "Sorption-desorption of lead (II) and mercury (II) by model associations of soil colloids," Soil Science Society of America Journal, vol. 67, no. 5, pp. 13781387, 2003.

[17] P. Miretzky, M. C. Bisinoti, W. F. Jardim, and J. C. Rocha, "Factors affecting $\mathrm{Hg}$ (II) adsorption in soils from the Rio Negro basin (Amazon)," Química Nova, vol. 28, no. 3, pp. 438443, 2005.

[18] FAO, "Word reference base for soil resources," World Soil Resources Rep. No. 84, FAO, Rome, 1998.
[19] M. M. Urrutia, E. García-Rodeja, and F. Macías, "Sulphide oxidation in coal-mine dumps: laboratory measurement of acidifying potential with $\mathrm{H}_{2} \mathrm{O}_{2}$ and its application to characterize spoil material," Environmental Management, vol. 16, no. 1, pp. 81-89, 1992.

[20] C. Aramburu and F. Bastida, Geología de Asturias, Ediciones Trea, Oviedo, Spain, 1995.

[21] R. Fernández-Martínez, J. Loredo, A. Ordóñez, and M. I. Rucandio, "Distribution and mobility of mercury in soils from an old mining area in Mieres, Asturias (Spain)," Science of the Total Environment, vol. 346, no. 1-13, pp. 200-212, 2005.

[22] Y. Otani, C. Kanaoka, H. Emi, I. Uchijima, and H. Nishino, "Removal of mercury vapor from air with sulfur-impregnated adsorbents," Environmental Science \& Technology, vol. 22, no. 6, pp. 708-711, 1988.

[23] S. V. Krishnan, B. K. Gullett, and W. Jozewicz, "Sorption of elemental mercury by activated carbons," Environmental Science \& Technology, vol. 28, no. 8, pp. 1506-1512, 1994.

[24] M. Hempel, R. D. Wilken, C. Geilhufe, and I. Richter-Politz, "Transformation of elemental mercury to organic mercury species at sites of former caustic soda plants in East-Germany," in Contaminated Soils, W. J. van den Brink, R. Bosman, and F. Arendt, Eds., pp. 505-506, Kluwer Academic Publishers, Dordrecht, The Netherlands, 1995.

[25] P. Miretzky, M. C. Bisinoti, and W. F. Jardim, "Sorption of mercury (II) in Amazon soils from column studies," Chemosphere, vol. 60, no. 11, pp. 1583-1589, 2005.

[26] B. Allard and I. Arsenie, "Abiotic reduction of mercury by humic substances in aquatic system-an important process for the mercury cycle," Water, Air, \& Soil Pollution, vol. 56, no. 1, pp. 457-464, 1991.

[27] D. G. Brookins, Eh-pH Diagrams for Geochemistry, Springer, New York, NY, USA, 1988.

[28] S. E. Lindberg, K.-H. Kim, T. P. Meyers, and J. G. Owens, "Micrometerorological gradient approach for quantifying air/surface exchange of mercury vapour: tests over contaminated soils," Environmental Science \& Technology, vol. 29, no. 1, pp. 126-135, 1995.

[29] K. Schlüter, "Review: evaporation of mercury from soils. An integration and synthesis of current knowledge," Environmental Geology, vol. 39, no. 3-4, pp. 249-271, 2000.

[30] S. M. Siegel and B. Z. Siegel, "Temperature determinants of plant-soil-air mercury relationships," Water, Air, \& Soil Pollution, vol. 40, no. 3-4, pp. 443-448, 1988.

[31] J. A. Ericksen and M. S. Gustin, "Foliar exchange of mercury as a function of soil and air mercury concentrations," Science of the Total Environment, vol. 324, no. 1-3, pp. 271-279, 2004.

[32] Y. Wang and M. Greger, "Clonal differences in mercury tolerance, accumulation, and distribution in willow," Journal of Environmental Quality, vol. 33, no. 5, pp. 1779-1785, 2004.

[33] S. E. Lindberg, D. R. Jackson, J. W. Huckabee, S. A. Janzen, M. J. Levin, and J. R. Lund, "Atmospheric emission and plant uptake of mercury from agricultural soils near the Almadén mercury mine," Journal of Environmental Quality, vol. 8, no. 4, pp. 572-578, 1979.

[34] S. E. Lindberg, T. P. Meyers, G. E. Taylor Jr., R. R. Turner, and W. H. Schroeder, "Atmosphere/surface exchange of mercury in a forest: results of modelling and gradient approaches," Journal of Geophysical Research, vol. 97, pp. 2519-2528, 1992. 

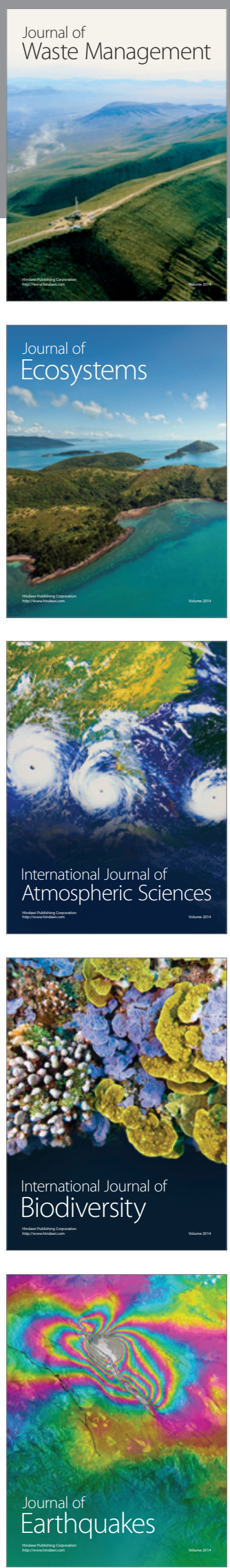
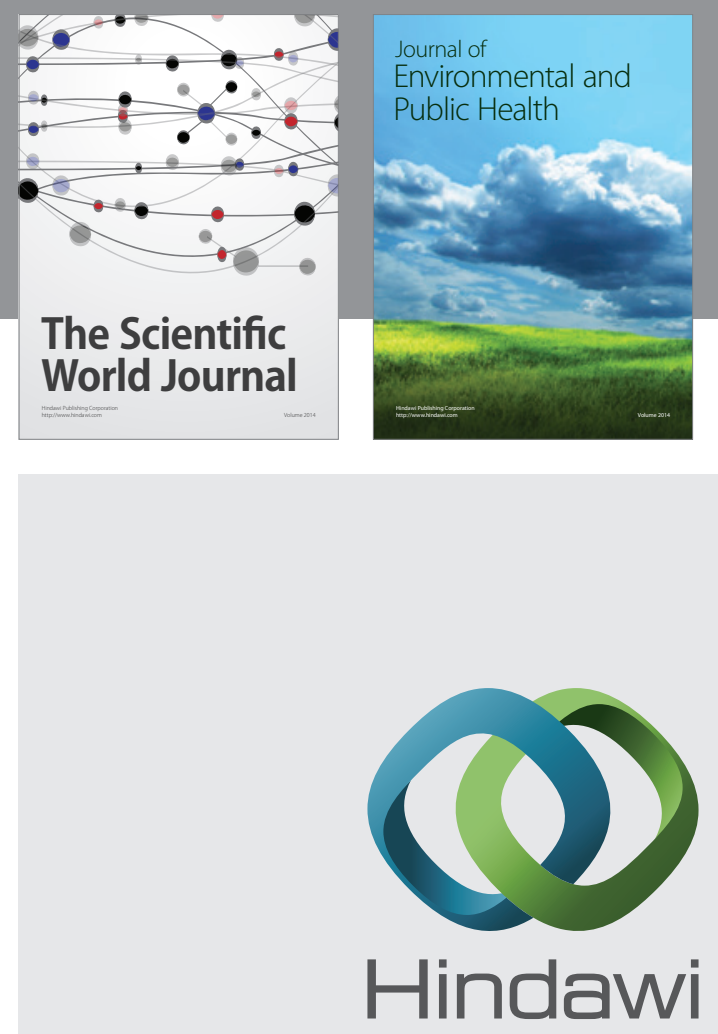

Submit your manuscripts at

http://www.hindawi.com
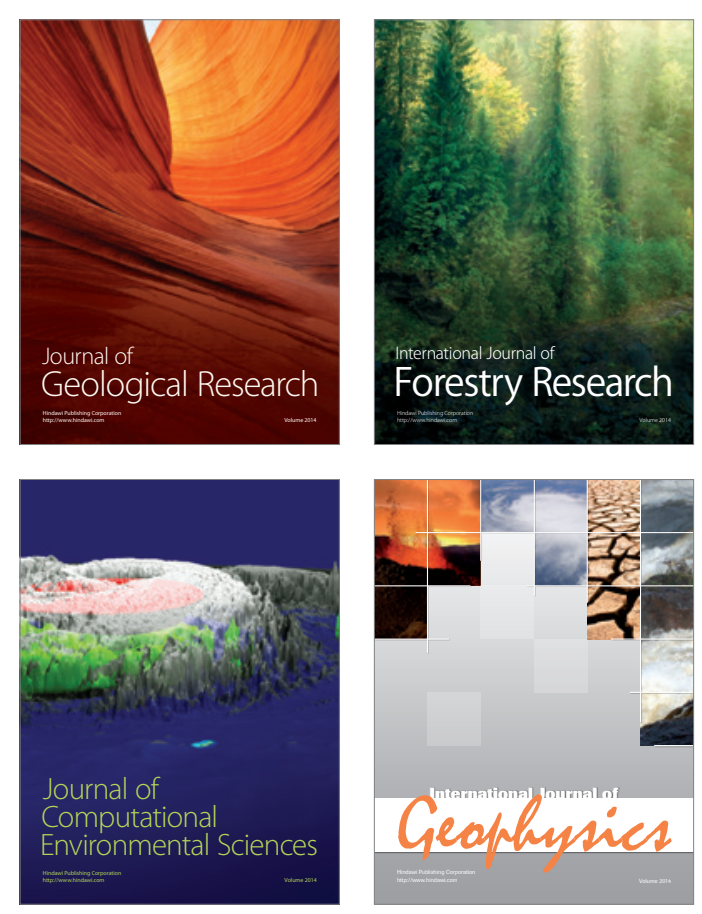
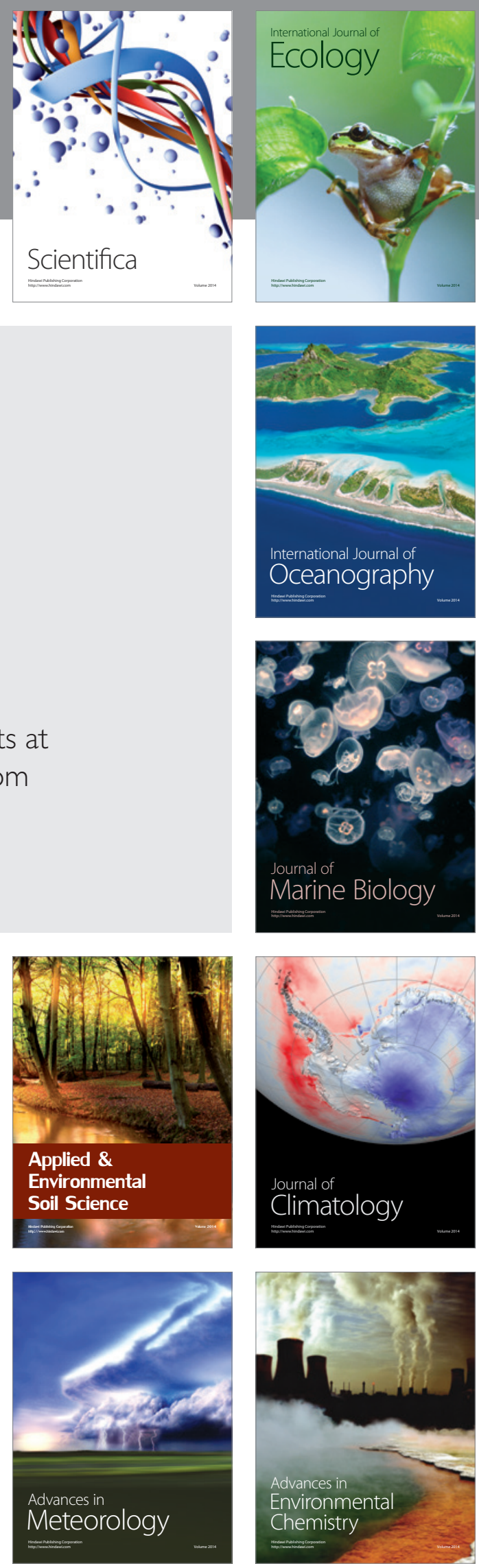